\title{
Rising JCV-Ab index during natalizumab therapy for MS
} Inauspicious for a highly efficacious drug

\section{OPEN}

Adil Javed, MD, PhD

Anthony T. Reder, MD

Correspondence to

Dr. Javed:

ajaved@neurology.bsd.uchicago.edu

Neurol Neuroimmunol

Neuroinflamm

2016;3:e199; doi: 10.1212/

NXI.0000000000000199
Infection with JC virus (JCV) is not noticeable and is usually inconsequential. Natalizumab therapy, however, blocks the very late antigen- 4 adhesion molecule on immune cells, preventing them from attaching to vascular cell adhesion molecule-1 on brain endothelial cells and then penetrating into the CNS. The dearth of $\mathrm{T}$ cells, and perhaps other factors, allows JCV to infect oligodendroglia and cause progressive multifocal leukoencephalopathy (PML), at a risk of $1 / 1,000$ per year. In this issue of Neurology ${ }^{\circledR}$ Neuroimmunology \& Neuroinflammation, Schwab et al. ${ }^{1}$ find that natalizumab markedly increases levels of the JCV antibodies that may foretell the risk of PML.

Prevalence of JCV infection in non-multiple sclerosis (MS) and MS populations is roughly $1 \%$ for every year of age, with an increase of $1 \%$ per year in the United States. ${ }^{2}$ International rates differ, with similarly low rates in England, Ireland, and Australia, but higher rates in Austria, Portugal, and Turkey. Race and type of MS have no effect on JCV positivity.

Interferon (IFN) $-\beta$ and glatiramer therapy for MS do not increase JCV prevalence, and IFN- $\beta$ reduces JCV viremia (circulating JCV DNA). Immunosuppressive and glucocorticoid therapy debatably increase the rate of JCV-positive sera. Recent cases of PML with 2 new oral agents mandate study of their effects on JCV. Natalizumab therapy, in large but relatively short-term MS studies, did not modify the frequency of JCV + sera. $^{3}$ Schwab et al. call this into question, and suggest that natalizumab markedly increases the rate of seroconversion.

A second-generation ELISA, recently in wide use, allows accurate detection of serum antibodies to JCVlike particles and then quantitation of $\mathrm{Ab}$ titers. This JCV index reflects the degree of humoral immunity to circulating virus proteins. Higher titers suggest the immune system has been re-exposed to viral particles or to the virus itself, and implicate new enhanced replication of virus or inadequacy of cell-mediated immunity, the main force controlling virus spread.

Schwab et al. studied 525 natalizumab-treated patients from Germany $(55 \% \mathrm{JCV}+)$ and 711 from France $(59 \%)$ in a paired, longitudinal design, using this ELISA. The 2 groups of patients seroconverted from negative to positive at rates of $10.3 \%$ and $8.5 \%$ per year, far more than the expected rate of $1 \%$ in healthy controls and in patients with MS not treated with natalizumab. JCV indexes also rose, at 0.091 units (13\%) per year. Their data extend earlier paired, longitudinal studies of natalizumab-treated patients with similar high rates of conversion and a rise in titers. In 470 German patients followed for nearly 8 months, using the first-generation assay, the annualized conversion to JCV+ was $8 \%$ per year. ${ }^{4}$ In 340 French patients, the conversion rate using first-generation then second-generation ELISA assays was $27 \%$ over 1 year. $^{5}$ In 340 patients from London, conversion to JCV+ with this second-generation assay, per year, was $6 \%$ at $0-2$ years, $10 \%$ at $2-4$ years, and $7 \%$ at $4-7$ years; the JCV index increase was $0.09,0.22$, and 0.11 during the same periods. ${ }^{6}$ In 111 patients from Chicago, the conversion rate was $9 \%$ per year. ${ }^{7}$ The rise in anti-JCV titers in this current article did not correlate with age, but did appear to rise most when the index is high (figure 3C). Arndt et al. ${ }^{7}$ used Bland-Altman statistics to show that JCV-Ab index values are most variable above a threshold of 1.5 units on repeat testing, and that the values rise over time.

The JCV index appears to be a valid serum marker of risk for PML, with $<0.9$ units $=$ minimal risk and $>1.5=$ increased risk. ${ }^{8}$ Other makers could add to its predictive value in the future. L-selectin on T cells initiates the initial slowing and rolling step of adhesion; low L-selectin expression reduces transmigration through the blood-brain barrier (BBB) and increases the risk of PML 55-fold. ${ }^{9}$ Other potential blood markers include human leukocyte antigen subtypes, viral DNA content in circulating $\mathrm{B}$ cells, and numbers of cytolytic $\mathrm{T}$ cells, interleukin-10+ T cells, or anti-JCV effector memory T cells. ${ }^{10}$

\section{See article}

From the University of Chicago, IL.

Funding information and disclosures are provided at the end of the article. Go to Neurology.org/nn for full disclosure forms.

This is an open access article distributed under the terms of the Creative Commons Attribution-NonCommercial-NoDerivatives License 4.0 (CC BY-NC-ND), which permits downloading and sharing the work provided it is properly cited. The work cannot be changed in any way or used commercially. 
The rapid seroconversion and rise in JCV index may herald PML during MS therapy and may be a clue to the genesis of PML. A higher index suggests that there is enhanced replication of the JCV outside of the renal reservoir in other tissues, including the brain. The brain is a relatively immune-privileged site. Natalizumab amplifies the immune escape by reducing CSF CD $4>$ CD8 $>>$ Th17 (minimal change) cells and lowering CSF immunoglobulin levels. Natalizumab also releases JCV + stem cells and $\mathrm{B}$ cells from the bone marrow; some penetrate the BBB. The virus burden may increase peripherally and centrally; cell-mediated immunity to the virus declines in both compartments. The natalizumab-induced Spi-B transcription factor enhances production of the pathogenic neurotropic variants that infect and destroy oligodendrocytes. These variants do not appear to be transmissible, based on epidemiology. Virus draining from the brain into cervical lymph nodes may also trigger antibody production, raising the JCV index.

Risk is relative. Despite a higher JCV replication state, an increase in JCV-Ab index does not necessarily mean that PML infection is imminent. Markers that quantify risk can give an edge in life's gambles. Our risk of death from driving to work in Illinois is $1 / 10,000$ per year; the risk of PML in $\mathrm{JCV}+$ natalizumab-treated patients without prior immunosuppressant therapy is 1:1,000 per year; the risk of an MS attack in untreated patients is $1 / 2$ per year. Schwab et al. extend growing observations that JCV-Ab index values need to be (monitored) and that seroconversion or rising JCV-Ab titers alter the risk of PML in patients treated with natalizumab.

\section{DISCLOSURE}

Dr. Javed has consulted for Bayer, Biogen, Questcor, Novartis, and Teva Neuroscience. Dr. Reder served on the scientific advisory boards, consulted for, and received travel funding and/or speaker honoraria from Abbott, ImmunoScience, Inc., Questcor/Malinkrodt, AstraZeneca, Merck Serono, Athena Diagnostics, Inc., Sanofi-Aventis, Bayer, Biogen Idec, BioMS Medical, Blue Cross Blue Shield, Boehringer Ingelheim, Caremark $\mathrm{Rx}$, Centocor Ortho Biotech Inc., Cephalon, Inc., Connetics Corp., CroMedica Global Inc., Eli Lilly and Company, Elan Corporation, Genentech, Inc., Genzyme Corporation, GlaxoSmithKline, Hoechst Marion Roussel Canada Research, Inc., Roche, Immunex Corporation, Institute for Health Care Quality, Johnson \& Johnson, Yale University, Barrow Neurological Institute, National Multiple Sclerosis Society \& Paralyzed
Veterans of America, Neurocrine Biosciences, Novartis, Parke-Davis, Pfizer Inc., Pharmacia \& Upjohn, Protein Design Labs, Inc., Quantum Biotechnologies, Inc., Quintiles, Inc., EMD Serono, Inc., Sention, Inc., Smith Kline- Beecham, Specialized Therapeutics (a division of Berlipharm, Inc., Takeda Pharmaceutical Company Limited), and Teva Pharmaceutical Industries Ltd.; received research support from Novartis, Bayer, Serono, Inc., Chugai, Genzyme, Biogen Idec, Medimmune Genentech/Roche, Inc., NIH/NINDS RO1 NS 051591, Site PI, NIH 1 K24 RR021948, PI, the Chinese government, Turkish Ministry of Defense Fellowship Award, and the State of Illinois; and is on the editorial board for Medlink/Neurobase, Arbor Publishing Corporation, Turkish Journal of Medical Sciences, Türk Nöroloji Dergisi (Turkish Journal of Neurology), the National MS Society, the Brain Research Foundation, the American Academy of Allergy \& Immunology, Howard Hughes Foundation, and Egypt Arab Republic Peace Fellowship. Go to Neurology. org/nn for full disclosure forms.

\section{REFERENCES}

1. Schwab N, Schneider-Hohendorf T, Pignolet B, et al. Therapy with natalizumab is associated with high JCV seroconversion and rising JCV index values. Neurol Neuroimmunol Neuroinflamm 2016;3:e195. doi: 10. 1212/NXI.0000000000000195.

2. Kean JM, Rao S, Wang M, Garcea RL. Seroepidemiology of human polyomaviruses. PLoS Pathog 2009;5: e1000363.

3. Bozic C, Subramanyam M, Richman S, Plavina $T$, Zhang A, Ticho B. Anti-JC virus (JCV) antibody prevalence in the JCV epidemiology in MS (JEMS) trial. Eur J Neurol 2014;21:299-304.

4. Trampe AK, Hemmelmann C, Stroet A, et al. Anti-JC virus antibodies in a large German natalizumab-treated multiple sclerosis cohort. Neurology 2012;78:1736-1742.

5. Outteryck O, Zephir H, Salleron J, et al. JC-virus seroconversion in multiple sclerosis patients receiving natalizumab. Mult Scler Epub 2013 Sep 26.

6. Raffel J, Gafson AR, Malik O, Nicholas R. Anti-JC virus antibody titres increase over time with natalizumab treatment. Mult Scler 2015;21:1833-1838.

7. Arndt N, Reder AT, Javed A. Variability of John Cunningham virus (JCV) index in multiple sclerosis patients treated with natalizumab in routine clinical practice. Barcelona, Spain: ECTRIMS; 2015:P616.

8. Plavina T, Subramanyam M, Bloomgren G, et al. Anti-JC virus antibody levels in serum or plasma further define risk of natalizumab-associated progressive multifocal leukoencephalopathy. Ann Neurol 2014;76:802-812.

9. Schwab N, Schneider-Hohendorf T, Pignolet B, et al. PML risk stratification using anti-JCV antibody index and L-selectin. Mult Scler Epub 2015 Oct 2.

10. Antoniol C, Stankoff B. Immunological markers for PML prediction in MS patients treated with natalizumab. Front Immunol 2014;5:668. 


\title{
Neurology \\ Neuroimmunology \& Neuroinflammation
}

\author{
Rising JCV-Ab index during natalizumab therapy for MS: Inauspicious for a highly \\ efficacious drug \\ Adil Javed and Anthony T. Reder \\ Neurol Neuroimmunol Neuroinflamm 2016;3; \\ DOI 10.1212/NXI.0000000000000199
}

This information is current as of January 27, 2016

Updated Information \&

Services

References

Subspecialty Collections

Permissions \& Licensing

Reprints including high resolution figures, can be found at:

http://nn.neurology.org/content/3/1/e199.full.html

This article cites 7 articles, 0 of which you can access for free at: http://nn.neurology.org/content/3/1/e199.full.html\#\#ref-list-1

This article, along with others on similar topics, appears in the following collection(s):

Multiple sclerosis

http://nn.neurology.org//cgi/collection/multiple_sclerosis

Information about reproducing this article in parts (figures,tables) or in its entirety can be found online at:

http://nn.neurology.org/misc/about.xhtml\#permissions

Information about ordering reprints can be found online: http://nn.neurology.org/misc/addir.xhtml\#reprintsus

Neurol Neuroimmunol Neuroinflamm is an official journal of the American Academy of Neurology.

Published since April 2014, it is an open-access, online-only, continuous publication journal. Copyright $\odot$ 2016 American Academy of Neurology. All rights reserved. Online ISSN: 2332-7812.

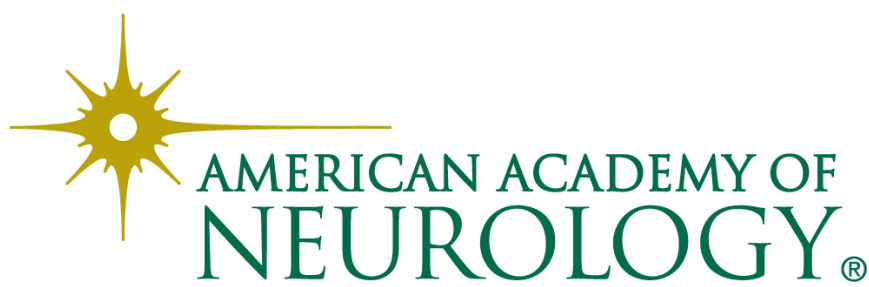

